\title{
The Relationship Between Stock Markets Of Major Developed Countries And Asian Emerging Markets
}

\author{
WING-KEUNG WONG ${ }^{\dagger}$ \\ Department of Economics, National University of Singapore \\ JACK PENM \\ Faculty of Economics and Commerce, Australian National University \\ RICHARD DEANE TERRELL \\ National Graduate School of Management, Australian National University \\ KAREN YANN CHING LIM \\ Department of Economics, National University of Singapore
}

\begin{abstract}
With the emergence of new capital markets and liberalization of stock markets in recent years, there has been an increase in investors' interest in international diversification. This is so because international diversification allows investors to have a larger basket of foreign securities to choose from as part of their portfolio assets, so as to enhance the reward-to-volatility ratio. This benefit would be limited if national equity markets tend to move together in the long run. This paper thus studies the issue of co-movement between stock markets in major developed countries and those in Asian emerging markets using the concept of cointegration. We find that there is co-movement between some of the developed and emerging markets, but some emerging markets do differ from the developed markets with which they share a long-run equilibrium relationship. Furthermore, it has been observed that there has been increasing interdependence between most of the developed and emerging markets since the 1987 Stock Market Crash. This interdependence intensified after the 1997 Asian Financial Crisis. With this phenomenon of increasing co-movement between developed and emerging stock markets, the benefits of international diversification become limited.
\end{abstract}

Keywords: Developed market, emerging market, stock index, unit root test, cointegration.

\section{Introduction}

In recent years, new capital markets have emerged in many parts of the world, and some foreign capital controls have been relaxed to a certain

$\dagger$ Requests for reprints should be sent to Wing-Keung Wong, Department of Economics, National University of Singapore. 
extent. This relaxation of capital controls started with the stock market liberalization when the United States took an important step by passing the U.S. Securities Act Amendments of 1975, which deregulated stock brokerage commission rates. Following the passing of this Act, the world stock markets experienced a series of deregulations and internationalization. In October 1979, exchange controls on capital outflows were eliminated in the United Kingdom. This easing on both the inflow and outflow of capital is significantly observed after 1980 (Taylor and Tonks, 1989). The Japanese capital market, conventionally known to be under stringent control (until the 1970s), also carried out a brief deregulation in 1978-1979 where foreign capital controls were slightly relaxed. With the implementation of the Foreign Exchange and Foreign Trade Control Law in December 1980, most capital controls in Japan were virtually abolished. As a result, trade of foreign financial assets by Japanese security firms and Japanese securities by foreign companies were permitted.

As for the Asian emerging markets, they have been liberalized at different times as summarized in Table $1^{1}$. Three different indicators of liberalization: the Official Liberalization Date, the First Country Fund and the First ADR are shown. The latter two indicators signify indirect ways of foreign participation in local stock markets, which are usually available before the lifting of various restrictions on foreign investors. From these signals of liberalization, the Asian countries had either liberalized or started the process of liberalization by the early 1990s. However, it should be noted that although these emerging countries have officially liberalized their stock markets, various degrees of direct and indirect barriers, still existed for institutional investors at the end of $1989^{2}$ [see Harrison (1994), such barriers being shown in Table 2].

Table 1. Different Signals of Stock Market Liberalization.

\begin{tabular}{|c|c|c|c|}
\hline Country & Official Liberalization Date & First country Fund & First ADR \\
\hline Hong Kong & January $1973^{a}$ & - & - \\
\hline Indonesia & September $1989^{b}$ & February $1989^{b}$ & April $1991^{c}$ \\
\hline Malaysia & December $1988^{b}$ & December $1987^{b}$ & August $1992^{b}$ \\
\hline Philippines & June $1991^{c}$ & May $1986^{b}$ & March $1991^{b}$ \\
\hline Singapore & June $1978^{a}$ & - & - \\
\hline Thailand & September $1987^{c}$ & July $1985^{b}$ & January $1991^{b}$ \\
\hline Korea & January $1992^{b}$ & August $1984^{b}$ & November $1990^{b}$ \\
\hline Taiwan & January $1991^{b}$ & May $1986^{b}$ & December $1991^{b}$ \\
\hline
\end{tabular}


With this relaxation of capital controls, there has been an increase in investors' interest in international diversification because it allows investors to have a larger basket of foreign securities to choose from as part of their portfolio assets so as to enhance the reward-to-volatility ratio. The benefit of international diversification, however, is limited when equity markets are cointegrated, because the presence of common factors limits the amount of independent variation. Cointegration among national equity markets implies that there are fewer assets available to investors to achieve portfolio diversification and so minimize the non-systematic risk in holding a certain number of stocks. Moreover, cointegration would also mean Granger Causality in levels and hence would be suggestive of inefficiency in the market [see Hung and Cheung (1995)].

Table 2. Emerging Stock Markets Direct and Indirect Barriers for Institutional Investors.

\begin{tabular}{|l|lllll|}
\hline Country & $\begin{array}{l}\text { Foreign } \\
\text { ownership limit }\end{array}$ & $\begin{array}{l}\text { Dividends } \\
\text { Repatriation }\end{array}$ & $\begin{array}{l}\text { Capital } \\
\text { Repatriation }\end{array}$ & $\begin{array}{l}\text { Withhold taxes } \\
\text { on dividend }\end{array}$ & $\begin{array}{l}\text { Taxes on } \\
\text { capital gains }\end{array}$ \\
\hline Hong Kong & $100 \%$ & Free & Free & $0 \%$ & $0 \%$ \\
Indonesia & $49 \%(25 \%)^{a}$ & Free & Free & $20 \%$ & $20 \%$ \\
Malaysia & $100 \%^{b}$ & Free & Free & $35 \%(0 \%)$ & $0 \%$ \\
Philippines & $40 \%^{d}$ & Free & Free & $15 \%$ & $0.25 \%$ \\
Singapore & $100 \%$ & Free & Free & $0 \%$ & $0 \%$ \\
Thailand & $49 \%(25 \%)^{e}$ & Free & Free & $20 \%(10 \%)$ & $25 \%(10 \%)$ \\
Korea $^{c}$ & $10 \%(8 \%)^{f}$ & Restrictions $^{g}$ & Restrictions & \\
Taiwan $^{c}$ & Special Funds $^{h}$ & Free & Free & $25 \%(10-21.5 \%)$ & $0 \%(11-27 \%)$ \\
\hline
\end{tabular}

Sources: IFC's Factbook, Harrison, 1994, The Euromoney Annual Report and the Exchange Arrangements and Restrictions, IMF.
Rates shown in brackets on withholding taxes on dividends and capital gains apply only to approved new Country Funds,

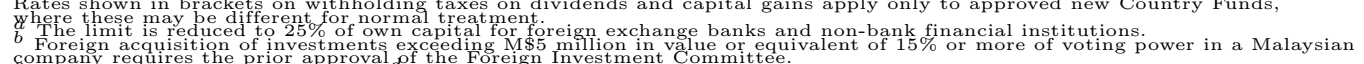

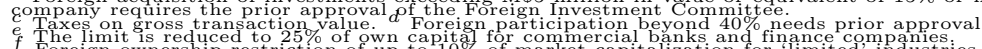

With such a likelihood that the benefits of international diversification may be reduced, this study is thus interested in investigating if Asian emerging equity markets (Malaysia, Thailand, Korea, Taiwan, Singapore and Hong Kong) do indeed move together with the stock markets of major developed countries (United States, United Kingdom, Japan). To do this we use the concept of cointegration, so that the right market can be chosen for portfolio diversification. Although the inclusion of Singapore and Hong Kong in the emerging markets category may be doubted by some, they are included in this paper to achieve a more thorough analysis. Our hypothesis is that as Japan is a major investor and trading partner, and has political influence on many Asian countries, it is expected that financial markets of Tokyo and the Asian countries may be related. Likewise, due to the size 
and world economic importance of the United States and United Kingdom markets, these markets potential influence on the emerging markets cannot be ignored. In addition, the trend of interdependence among the abovementioned developed and emerging markets has also been analyzed over time, for the periods before and since the 1987 Stock Market Crash and the 1997 Asian Financial Crisis.

As discussed in next section, some studies suggest that the Asian Emerging markets are cointegrated with the developed stock markets while some suggest not. We revisit the issue and find that there is co-movement between some of the developed and emerging markets. In addition, there is increasing interdependence between most of the developed and emerging markets after the 1987 Stock Market Crash. This interdependence is further intensified after the 1997 Asian Financial Crisis.

The rest of the paper is organized as follows: Section 2 reports the literature review and Section 3 describes the statistical data, conceptual framework and elaborates on the methodology used. Section 4 discusses the empirical findings and interprets the results, and Section 5 is a brief conclusion.

\section{Literature Review}

When investment decisions are made, investors may choose different types of diversification. One of the reasons why international diversification undertaken rather than just domestic diversification [see Levy and Sarnat (1970)] is that there is a tendency for returns on individual securities within an economy to move together. However, it is unlikely that the movements across a number of countries are related. Grubel and Fadner (1971) also found that there are gains from international diversification because returns in any one country are influenced by natural and man-made catastrophes, business cycles, and government policies whose effects are limited to or felt most strongly in the economy of that affected country. Also capital value changes of assets due to exchange rate variations influence the variance on returns on foreign assets from different countries. This benefit of international diversification is further elaborated on by Bodie, et al. (1999), who state that the risk of an internationally diversified portfolio can be reduced to less than half the level of a diversified United States portfolio. This marked reduction in risk for a portfolio that includes foreign as well as United States stocks further enhances the value of portfolio diversification, implying that international diversification is beneficial.

Early studies investigating relationships among world stock markets find evidence of co-movements among the world stock markets. Most of these 
early studies that we reviewed focus on the equity markets of the United States, Japan and Europe using pairwise analysis. Ripley (1973) uses factor analysis to explore interrelationships between the stock prices, Panton, et al. (1976) apply cluster analysis to examine similar relationships, while Hillard (1979) applies spectral methods to study the relationships among the international stock markets. However, Maldonado and Saunders (1981) examine inter-temporal patterns of the correlation coefficients among international stock markets and generally conclude that pairwise correlation coefficients are low and unstable.

With the United States being a major investor in many countries and posing a huge political influence on several countries in the world, studies have been done to investigate the causal relationship between the United States and other equity markets. Results indicate that the United States is an important global factor that moves the world markets. For example, Eun and Shim (1989) examine nine major stock markets (Australia, Canada, France, Germany, Hong Kong, Japan, Switzerland, the United Kingdom and the United States) over the period of December 1979 through December 1985, and find evidence that the United States market is leading worldwide trends. Cheung and Mak (1992) examine the causal relationship between the developed markets and Asian emerging markets and find that the United States market is a 'global factor' which leads both the developed and most of the Asian emerging markets.

Some studies support the existence of a common trend for world stock markets, while others reject this hypothesis. Arshanapalli and Doukas (1993) analyze the stock markets of the United States, United Kingdom, France, Germany and Japan, using daily closing stock market index time series, in local currency units, covering the period of January 1980 through May 1990, and report an increasing degree of interdependence among world capital markets since the 1987 stock market crash, with Japan's Nikkei Index being the exception. This result is consistent with the findings of Harvey (1991), Kasa (1992) and Chan, et al. (1997). However, Koop (1994) uses a variety of different Bayesian methods to analyze unit root and cointegration properties of two different finance data sets, and concludes that there are no common trends in stock prices or exchange rates across countries. In addition Corhay, et al. (1995) study the stock markets of Australia, Japan, Hong Kong, New Zealand and Singapore over the period February 1972 through February 1992 and find no evidence of a single stochastic trend for the countries.

With the emergence of Asian capital markets, studies have been done in the 1990s and thereafter to study the co-movements between Asian markets and the stock markets in developed countries. Kwan, et al. (1995) study 
the stock markets of Australia, Hong Kong, Japan, Singapore, South Korea, Taiwan, United Kingdom, United States and Germany. They suggest that these markets are not weak form efficient as they find significant lead-lag relationships between these equity markets. However, Chan, et al. (1992) and Hung and Cheung (1995) conclude that these Asian markets are not cointegrated. Recently, Ghosh, et al. (1999) find that some Asian stock markets share a long-run equilibrium relationship with the major stock markets, while some do not. Recently, Tuluca and Zwick (2001) apply Granger-causality technique to study the stock indices difference and apply factor analysis to study the stock indices returns among 13 Asian and nonAsian stock markets before and after the 1997 Asian financial crises. They conclude that these markets experienced a stronger co-movement after the crisis.

Clearly the above studies are not directly comparable as different differencing intervals (daily, weekly, monthly, quarterly) and methodologies are employed with different time periods and different market indices as measures of the respective markets. Hence these studies do draw different conclusions about the relationships between the Asian emerging markets and the major developed stock markets.

\section{Data and Methodology}

The data used in this study consists of weekly stock indices of the major stock exchange in the United States, United Kingdom, Japan, Malaysia, Thailand, Korea, Taiwan, Singapore and Hong Kong ${ }^{3}$. Specifically, the indices sampled include the S\&P 500 Composite (United States), FTSE 100 (United Kingdom), Nikkei 225 Stock Average (Japan), Kuala Lumpur Composite (Malaysia), Bangkok S.E.T. (Thailand), Korea SE Composite (Korea), Taiwan SE Composite (Taiwan), Straits Times Index (Singapore) and Hang Seng (Hong Kong), all expressed in terms of local currencies. The data are obtained from Datastream and cover the period January 1, 1981 through December 31, 2002. The choice of weekly indices as opposed to daily indices is to avoid the problem of non-synchronous trading when daily indices are in use, as daily indices may be influenced by some thinly traded stocks. An erroneous representation of the true relationships among these markets may thus result if daily indices are used (Hung and Cheung, 1995).

To examine the trend of interdependence between the developed and emerging markets over time, the stock indices from the sample are further sub-divided into three sub-periods: January 1, 1981 - December 31, 1986 (Period I), January 1, 1987 - December 311996 (Period II) and January 
1, 1997 - December 31, 2002 (Period III). The Stock Market Crash (Black Monday) ${ }^{4}$ of 1987 separates Period I and II. For Periods II and III, the 1997 Asian Financial Crisis ${ }^{5}$ separates them.

In studying the question of co-movements between the stock indices of major developed countries and Asian emerging markets, the relationship between them has to be established. The model consists of the dependent variables: Malaysia, Thailand, Korea, Taiwan, Singapore and Hong Kong and independent variables: United States, United Kingdom and Japan. This analysis is thus played by the relationship

$$
y_{E}(t)=a+b y_{D}(t)+e(t)
$$

where the subscript $E$ denotes the emerging market's stock index (i.e. the stock indices for Malaysia, Thailand, Korea, Taiwan, Singapore and Hong Kong). The subscript $D$ denotes the developed country's stock index (i.e. stock indices for the United States, United Kingdom and Japan) and $\mathrm{e}(\mathrm{t})$ denotes the error term. The statistical concept of cointegration plays a major role in determining the validity and reliability of the relationship specified above. Cointegration is thus required in order to reach the conclusion of a stable equilibrium relationship between the stock indices of the developed and emerging markets.

The concept of cointegration, which is used to analyze if variables share a long-run equilibrium relationship will be used in our study. In order to test for cointegration, a unit root test [see Dickey and Fuller (1981), Hamilton (1994), Tiku and Wong (1998) and Tiku et al. (2000)], (Dickey Fuller and Augmented Dickey Fuller tests) first has to be performed to confirm that the variables are indeed stationary. Cointegration tests, which are important in determining the presence and nature of an equilibrium economic relation, was first introduced by Granger (1981) and later developed by Granger (1987). It incorporates the presence of non-stationarity, long-term relationships and short-run dynamics in the modeling process. A detailed description of cointegration can be found in Dolado, et al. (1990), Perman (1991), Hamilton (1994), Manzur, et al. (1999) and Penm, et al. (2003).

Cointegration tests in this paper consist of two steps. The first step is to examine the stationarity properties of the various stock indices for the countries in our study. If a series, say $y_{t}$, has a stationary, invertible and stochastic ARMA representation after differencing d times, it is said to be integrated of order $d$, and denoted as $y_{t}=I(d)$. Most non-stationary series are integrated of order one, i.e. $I(1)$. We call a stationary series to be integrated of order zero, i.e. $I(0)$. To test the null hypothesis $H_{0}: y_{t}=I(1)$ versus the alternative hypothesis that $H_{1}: y_{t}=I(0)$, we apply the Dickey- 
Fuller (1981) unit root test procedure based on the OLS regression

$$
\nabla y_{t}=\beta_{0}+\alpha_{0} t+\alpha_{1} y_{t-1}+\varepsilon_{t}
$$

or apply the augmented Dickey-Fuller (ADF) test based on the OLS regression

$$
\nabla y_{t}=\beta_{0}+\alpha_{0} t+\alpha_{1} y_{t-1}+\sum_{i=1}^{p} \beta_{i} y_{t-i}+\varepsilon_{t}
$$

where $\nabla y_{t}=y_{t}-y_{t-1}$ and $y$ can be $y_{D}$ or $y_{E}$ as defined in (1). The regression in (2) allows for a drift term, a deterministic trend and a stochastic structure in the error term, $\varepsilon_{t}$. We use the Ljung-Box-Pierce Q-statistic [see Box et al. (1994)], to select the shortest auto-regressive lag $p$ in equation (3) to achieve white noise residuals. Testing the null hypothesis of the presence of a unit root in $y_{t}$ (i.e. the series is $I(1)$ ) is equivalent to testing the hypothesis that $\alpha_{1}=0$ in equations (2) and (3). If $\alpha_{1}$ is significantly less than zero, the null hypothesis of a unit root is rejected. The test statistic used is the usual t-ratio, but the distribution is not the tdistribution under the null hypothesis. When $p=0$, the test is known as the Dickey-Fuller (DF) test. This test assumes that the residuals, $\varepsilon_{t}$, are independently and identically distributed. If serial correlation exists in the residuals, then $p>0$ and the augmented Dickey-Fuller (ADF) test must be applied.

In addition, we test the hypothesis that $y_{t}$ is a random walk with drift, i.e. $\left(\beta_{0}, \alpha_{0}, \alpha_{1}\right)=\left(\beta_{0}, 0,0\right)$ and test the hypothesis that $y_{t}$ is a random walk without drift, i.e. $\left(\beta_{0}, \alpha_{0}, \alpha_{1}\right)=(0,0,0)$ using the regression $(2)$. The corresponding test statistics are the likelihood ratios $\Phi_{3}$ and $\Phi_{2}$ found in Dickey and Fuller (1981). If the hypotheses that $\alpha_{1}=0,\left(\beta_{0}, \alpha_{0}, \alpha_{1}\right)=$ $\left(\beta_{0}, 0,0\right)$ or $\left(\beta_{0}, \alpha_{0}, \alpha_{1}\right)=(0,0,0)$ are accepted, we may conclude that $y_{t}$ is an integrated process of order 1 . If we do not reject the hypotheses that $y_{t}$ is $I(1)$, we then test the null hypothesis $H_{0}: y_{t}=I(2)$ versus the alternative hypothesis that $H_{1}: y_{t}=I(1)$. If both $y_{D}$ and $y_{E}$ in equation (1) are of the same order, say $I(1)$, we then estimate the cointegrating parameter of (1) by OLS regression. If the two series are cointegrated, then the residuals of the regression using (1) will be stationary. If the two series are not cointegrated, the residuals will be integrated of order 1 .

The two most common tests for stationarity of estimated residuals are Cointegrating Regression Dickey-Fuller (CRDF), and Augmented DickeyFuller (CRADF) tests. To compute the CRDF and CRADF statistics, we fit the following regression:

$$
\nabla \hat{e}_{t}=\gamma \hat{e}_{t-1}+\sum_{i=1}^{p} \gamma_{i} \hat{e}_{t-i}+\zeta_{t}
$$


where $\hat{e}_{t}$ are residuals from the cointegrating regression and $p$ is chosen to achieve empirical white noise residuals being checked by using the LjungBox-Pierce Q-statistic. The null hypothesis of non-cointegration is rejected if the t-ratio is less than the relevant critical value. Engle and Granger (1987) have tabulated these critical values for the case where $p=0$ (CRDF) and for $p>0$ (CRADF) for the bivariate regression with a sample of 100 observations.

\section{Empirical Findings and Interpretation}

Table 3 shows the results of testing the order of integration of the nine series for the entire period of 1981-2002, and each of the sub-periods. From the table there is no reason to reject there are unit roots for all the stock indices of the developed and emerging markets at the $5 \%$ significance level for the entire period, as well as for each sub-period. We conclude that all stock indices in our study are $I(1)^{6}$ and hence cointegrating equation (1) can be used to regress the stock indices of the emerging market on those of the developed markets. The unit root test on the residuals from equation (4) is then applied to test the hypothesis of cointegration. When Asian stock markets open after the United States and United Kingdom stock markets, some researchers may believe there is some lead-lag effect among different stock markets [see Kwan, et al. (1995)]. For countries in which the results show that the stock indices between the developed and emerging markets are not cointegrated, cross-correlation is then employed to account for any lead-lag effects on the stock indices. Our findings ${ }^{7}$ show that in this latter case there are no strong lead-lag effects. Nevertheless the results originally obtained indicate a good measure of co-movement between stock indices between the developed and emerging markets. One possible explanation of no lead-lag effect in our findings is that we use weekly data, which have time aggregative effects.

The results of cointegration are shown in Table 4. For the entire period, from the table, we find no cointegration between the emerging markets of Malaysia, Thailand and Korea and the developed markets of the United States, United Kingdom and Japan. The indices of both Taiwan and Singapore are only cointegrated with the stock market of Japan, while the index of Hong Kong is cointegrated with both the stock markets of the United States and United Kingdom for the entire period. No other cointegration is found for the entire period. Lack of cointegration in the entire period may be due to the fact that the period is so long that many changes in the market conditions have been incorporated for different countries. To overcome these limitations, we further investigate the cointegration in the three 
Table 3. Unit Root Tests for Various Stock Market Indices.

\begin{tabular}{|c||l|llll||l|llll|}
\hline Variable & Period & DF & ADF & $\Phi_{2}$ & $\Phi_{3}$ & Period & DF & ADF & $\Phi_{2}$ & $\Phi_{3}$ \\
\hline US & $81-02$ & -1.49 & -1.1 & 1.91 & 1.12 & $81-86$ & -2.27 & -2.27 & 3.43 & 3.77 \\
- S\&P 500 & $87-96$ & -0.65 & -0.58 & $5.60^{*}$ & 1.66 & $97-02$ & -1.3 & -0.69 & 0.24 & 3.15 \\
\hline UK & $81-02$ & -1.22 & -0.9 & 0.81 & 1.13 & $81-86$ & -2.96 & -2.96 & 3.93 & 4.83 \\
- FTSE 100 & $87-96$ & -2.56 & -2.56 & $5.02^{*}$ & 3.49 & $97-02$ & -1.56 & -1.56 & 0.04 & 3.46 \\
\hline Japan- & $81-02$ & -1.13 & -1.27 & 0.52 & 2.48 & $81-86$ & -0.84 & -1.17 & $7.82^{* *}$ & 2.92 \\
Nikkei 225 & $87-96$ & -2.49 & -2.69 & 0.05 & 3.6 & $97-02$ & -1.91 & -1.7 & 1.07 & 1.91 \\
\hline Malaysia - & $81-02$ & -1.66 & -2.31 & 0.6 & 1.46 & $81-86$ & -1.64 & -2.01 & 0.37 & 1.4 \\
KL Composite & $87-96$ & -2.65 & -2.65 & 3.85 & 3.56 & $97-02$ & -2.33 & -2.61 & 4.3 & 3.68 \\
\hline Thailand - & $81-02$ & -0.96 & -1.27 & 0.2 & 1.08 & $81-86$ & 1.51 & -0.46 & $8.01^{* *}$ & $6.92^{*}$ \\
Bangkok S.E.T. & $87-96$ & -1.18 & -1.6 & 1.71 & 1.69 & $97-02$ & -2.94 & -2.94 & $5.88^{*}$ & 5.71 \\
\hline Korea- & $81-02$ & -1.68 & -1.58 & 0.62 & 1.68 & $81-86$ & 0.08 & 0.08 & 4.5 & 2.14 \\
SE Composite & $87-96$ & -1.89 & -1.89 & 0.13 & 3.76 & $97-02$ & -1.83 & -1.83 & 1.66 & 1.67 \\
\hline Taiwan - & $87-02$ & -1.9 & -1.9 & 0.57 & 1.97 & & & & & \\
SE Composite + & $87-96$ & -1.1 & -1.1 & 1.34 & 1.64 & $97-02$ & -2.69 & -2.69 & 0.58 & 3.74 \\
\hline Singapore- & $81-02$ & -1.78 & -2.02 & 0.55 & 2.09 & $81-86$ & -0.56 & -0.56 & 1.3 & 1.54 \\
ST Index & $87-96$ & -2.5 & -2.77 & 4.02 & 3.14 & $97-02$ & -1.48 & -1.48 & 1.04 & 1.11 \\
\hline Hong Kong - & $81-02$ & -2.4 & -2.4 & 3.19 & 2.92 & $81-86$ & -0.28 & -0.28 & 3.68 & 3.23 \\
HS Index & $87-96$ & -2 & -2 & 3.03 & 3.05 & $97-02$ & -1.68 & -1.68 & 1.01 & 1.48 \\
\hline
\end{tabular}

sub-periods: January 1, 1981 - December 31, 1986 (Period I), January 1, 1987 - December 31, 1996 (Period II) and January 1, 1997 - December 31, 2002 (Period III), separated by the 1987 Stock Market Crash and the 1997 Asian Financial Crisis.

The cointegration in the first sub-period in our study is striking: no cointegration between any of the Asian emerging markets and the developed markets of the United States, United Kingdom and Japan. This suggests that the Asian emerging markets are basically not influenced by any of the developed markets of the United States, United Kingdom and Japan before the 1987 crash.

For Period II, between the 1987 crash and the 1997 Asian Financial Crisis, Table 5 shows that there are some cointegration relationships between some of the Asian emerging markets and the developed markets of the United States, United Kingdom and Japan. In this period, Malaysia is cointegrated only with the United Kingdom; Thailand and Korea are cointegrated only with Japan; Singapore is cointegrated with Japan and the United Kingdom; while Hong Kong is cointegrated with the United States and the United Kingdom.

For Period III, after the 1997 Asian Financial Crisis, our results show that there are more cointegration relationships between some of the Asian emerging markets and the developed markets of the United States, United Kingdom and Japan. In this period, instead of not being cointegrated with any of the three developed markets in Period I and being cointegrated with only one developed market in Period II, Malaysia, Thailand and Hong Kong become cointegrated with all the three developed markets: the United States, the United Kingdom and Japan. Taiwan improves from no cointegration with any of the three developed markets in both Periods 
Table 4. Cointegration for Stock Indices of Major Developed Countries and Asian Emerging Markets.

\begin{tabular}{|c|c|c|c|c|c|c|c|}
\hline & & \multicolumn{3}{|c|}{$1981-2002$} & \multicolumn{3}{|c|}{ 1981-1986 } \\
\hline $\begin{array}{c}\text { Dependent } \\
\text { Variable }\end{array}$ & $\begin{array}{c}\text { Independent } \\
\text { Variable }\end{array}$ & $R^{2}$ & CRDF & CRADF & $R^{2}$ & $\mathrm{CRDF}$ & CRADF \\
\hline Malaysia & $\begin{array}{c}\text { U.S. } \\
\text { U.K. } \\
\text { Japan }\end{array}$ & $\begin{array}{l}25.72 \% \\
34.10 \% \\
2.48 \%\end{array}$ & $\begin{array}{l}-1.57 \\
-1.66 \\
-1.4\end{array}$ & $\begin{array}{l}-1.8 \\
-1.9 \\
-1.72\end{array}$ & $\begin{array}{l}33.11 \% \\
43.34 \% \\
39.31 \%\end{array}$ & $\begin{array}{l}-1.53 \\
-1.65 \\
-1.49\end{array}$ & $\begin{array}{l}-1.94 \\
-1.65 \\
-1.88\end{array}$ \\
\hline Thailand & $\begin{array}{c}\text { U.S. } \\
\text { U.K. } \\
\text { Japan }\end{array}$ & $\begin{array}{l}0.58 \% \\
14.78 \% \\
22.38 \%\end{array}$ & $\begin{array}{l}-1.27 \\
-0.97 \\
-1.32\end{array}$ & $\begin{array}{l}-1.49 \\
-1.28 \\
-1.47\end{array}$ & $\begin{array}{l}57.80 \% \\
57.32 \% \\
53.45 \%\end{array}$ & $\begin{array}{l}0.59 \\
1.39 \\
0.2\end{array}$ & $\begin{array}{l}-0.67 \\
-0.71 \\
-1.13\end{array}$ \\
\hline Korea & $\begin{array}{c}\text { U.S. } \\
\text { U.K. } \\
\text { Japan }\end{array}$ & $\begin{array}{l}20.51 \% \\
45.64 \% \\
40.77 \%\end{array}$ & $\begin{array}{l}-1.67 \\
-1.68 \\
-1.54\end{array}$ & $\begin{array}{l}-1.67 \\
-1.59 \\
-1.34\end{array}$ & $\begin{array}{l}65.81 \% \\
47.59 \% \\
76.39 \%\end{array}$ & $\begin{array}{l}-1.02 \\
0.05 \\
-1.44\end{array}$ & $\begin{array}{l}-0.73 \\
0.05 \\
-1.44\end{array}$ \\
\hline Taiwan $^{+}$ & $\begin{array}{c}\text { U.S. } \\
\text { U.K. } \\
\text { Japan }\end{array}$ & $\begin{array}{l}0.30 \% \\
17.32 \% \\
43.48 \%\end{array}$ & $\begin{array}{l}-1.49 \\
-1.9 \\
-2.42^{*}\end{array}$ & $\begin{array}{l}-1.49 \\
-1.9 \\
-2.42^{*}\end{array}$ & $\begin{array}{l}- \\
- \\
-\end{array}$ & $\begin{array}{l}- \\
- \\
-\end{array}$ & $\begin{array}{l}- \\
- \\
-\end{array}$ \\
\hline Singapore & $\begin{array}{c}\text { U.S. } \\
\text { U.K. } \\
\text { Japan }\end{array}$ & $\begin{array}{l}47.25 \% \\
61.32 \% \\
3.38 \%\end{array}$ & $\begin{array}{l}-1.9 \\
-1.78 \\
-2.11^{*}\end{array}$ & $\begin{array}{l}-1.9 \\
-1.78 \\
-2.19^{*}\end{array}$ & $\begin{array}{l}3.41 \% \\
7.63 \% \\
18.64 \%\end{array}$ & $\begin{array}{l}-0.38 \\
-0.61 \\
-0.86\end{array}$ & $\begin{array}{l}-0.38 \\
-0.61 \\
-0.86\end{array}$ \\
\hline Hong Kong & $\begin{array}{c}\text { U.S. } \\
\text { U.K. } \\
\text { Japan }\end{array}$ & $\begin{array}{l}82.48 \% \\
86.55 \% \\
0.01 \%\end{array}$ & $\begin{array}{l}-2.32^{*} \\
-2.68^{* *} \\
-1.23\end{array}$ & $\begin{array}{l}-2.32^{*} \\
-2.68^{* *} \\
-1.23\end{array}$ & $\begin{array}{l}33.61 \% \\
29.05 \% \\
42.57 \%\end{array}$ & $\begin{array}{l}-0.65 \\
-0.66 \\
-1.28\end{array}$ & $\begin{array}{l}-0.65 \\
-0.66 \\
-1.28\end{array}$ \\
\hline
\end{tabular}

+ denotes data is not available for Taiwan for the sub-period 1981-1986.

* $p<0.05, * * p<0.01$

I and II to being cointegrated with both Japan and the United Kingdom. However, Singapore is cointegrated with only the United States, and Korea remains no cointegration with any of these three developed markets in Period III.

We now attempt to explain the cointegration revealed in our findings. Phylaktis and Ravazzolo (2002) state that the co-movements between markets over time can be explained by economic integration. Other reasons, like economic relationships, regulatory structures, exchange rate policy and trade flows, which can account for the cointegration between two financial markets have been cited in previous literature. For the entire period of 1981-2002, it is observed that Singapore and Taiwan are co-moving with the Japanese market. A plausible reason to explain this relationship could be that Japan is a major investor in Singapore and Taiwan. The close links between Japan and Taiwan might stem from the substantial Japanese Foreign Direct investment (FDI) in Taiwan since the mid-1980s. This could account for the co-movements between the Japanese and Taiwanese stock markets for the period 1981-2002 and the sub-period 1997-2002. In partic- 
Table 5. Cointegration for Stock Indices of Major Developed Countries and Asian Emerging Markets.

\begin{tabular}{|c|c|c|c|c|c|c|c|}
\hline & & & $987-199$ & & & $1997-20$ & \\
\hline $\begin{array}{c}\text { Dependent } \\
\text { Variable }\end{array}$ & $\begin{array}{c}\text { Independent } \\
\text { Variable }\end{array}$ & $R^{2}$ & CRDF & CRADF & $R^{2}$ & CRDF & CRADF \\
\hline & U.S. & $82.82 \%$ & -1.94 & -1.94 & $2.46 \%$ & $-2.34^{*}$ & $-2.34^{*}$ \\
\hline Malaysia & U.K. & $88.51 \%$ & $-3.45^{* *}$ & $-3.06^{* *}$ & $6.64 \%$ & $-2.33^{*}$ & $-2.55^{*}$ \\
\hline & Japan & $27.19 \%$ & -1.86 & -1.95 & $25.61 \%$ & $-2.36^{*}$ & $-2.36^{*}$ \\
\hline & U.S. & $58.59 \%$ & -0.11 & -0.2 & $21.13 \%$ & $-2.85^{* *}$ & $-2.85^{* *}$ \\
\hline Thailand & U.K. & $78.33 \%$ & -1.2 & -1.68 & $36.12 \%$ & $-2.95^{* *}$ & $-2.95^{* *}$ \\
\hline & Japan & $20.96 \%$ & $-2.45^{*}$ & $-2.81^{* *}$ & $31.10 \%$ & $-3.10^{* *}$ & $-3.87^{* *}$ \\
\hline & U.S. & $19.57 \%$ & -1.84 & -1.84 & $8.34 \%$ & -1.73 & -1.73 \\
\hline Korea & U.K. & $30.89 \%$ & -1.9 & -1.9 & $5.90 \%$ & -1.83 & -1.83 \\
\hline & Japan & $1.38 \%$ & $-2.62^{* *}$ & $-2.62^{* *}$ & $5.61 \%$ & -1.7 & -1.7 \\
\hline & U.S. & $0.90 \%$ & -1.1 & -1.1 & $0.01 \%$ & -1.16 & -1.16 \\
\hline Taiwan & U.K. & $0.33 \%$ & -1.14 & -1.14 & $65.24 \%$ & $-2.69^{* *}$ & $-2.69^{* *}$ \\
\hline & Japan & $7.60 \%$ & -1.21 & -1.21 & $81.66 \%$ & $-3.78^{* *}$ & $-3.78^{* *}$ \\
\hline & U.S. & $78.87 \%$ & -1.64 & -1.64 & $19.11 \%$ & $-2.06^{*}$ & $-2.06^{*}$ \\
\hline Singapore & U.K. & $80.34 \%$ & $-2.51^{*}$ & $-2.51^{*}$ & $0.01 \%$ & -1.49 & -1.49 \\
\hline & Japan & $22.98 \%$ & $-2.02^{*}$ & $-2.25^{*}$ & $26.81 \%$ & -1.71 & -1.71 \\
\hline & U.S. & $86.68 \%$ & $-2.30^{*}$ & $-2.30^{*}$ & $26.63 \%$ & $-2.14^{*}$ & $-2.14^{*}$ \\
\hline Hong Kong & U.K. & $91.78 \%$ & $-3.39^{* *}$ & $-3.39^{* *}$ & $21.40 \%$ & $-2.00^{*}$ & $-2.00^{*}$ \\
\hline & Japan & $39.72 \%$ & -1.34 & -1.57 & $31.26 \%$ & $-2.03^{*}$ & $-2.03^{*}$ \\
\hline
\end{tabular}

ular, Japanese FDI accounts for about $27 \%$ of FDI stock in Taiwan during the mid-1980s [see Krenin, et al. (2000)]. This FDI later became increasingly export oriented, while at the same time a lot of parts and equipment were imported from Japan, thus strengthening the economic and financial links between Japan and Taiwan. This perhaps partially explains Taiwan and Japans co-movements in 1981-2002 and 1997-2002. Because the regulatory structures of Singapore and Taiwan are more closely related to those of Japan than the United States and the United Kingdom could also be another reason why the Singapore and Taiwan markets are cointegrated with Japan but not with the United States and the United Kingdom [see Ghosh, et al. (1999)].

In Hong Kong, United States multinational corporations are more prominent than in Singapore, and this may be the reason why its stock market shares a long-run equilibrium relationship with the stock market of the United States [see Ghosh, et al. (1999)]. This could also explain why the Singapore market does not move along with the United States market. Moreover, Hong Kong's exchange rate is pegged to the United States dollar and this contributes to the long run relationship between the United States 
and Hong Kong markets. The co-movements could also be due to Hong Kong having been a colony of the United Kingdom until 1997. As such, Hong Kong's economic relationships and regulatory structures are similar to those of the United Kingdom.

A finding that should be taken special notice of is that although Hong Kong is no longer a colony of the United Kingdom, results obtained for 1997-2002 show that the co-movement between the stock markets of Hong Kong and the United Kingdom still persists even though Hong Kong has been returned to China. As Hong Kong is a Special Administrative Region of China, and is running independently, it still retains many of the economic relationships and regulatory structures used while it was colonized. As such, the relationship of Hong Kong's stock market with that of the United Kingdom has not changed significantly since 1997. This contributes to the long-run equilibrium relationship between Hong Kong and the United Kingdom for the entire period of 1981-2002.

For Malaysia, Thailand and Korea, no relationship between them and the developed markets of the United States, United Kingdom and Japan has been found. As there are no co-movements between these markets and the major developed markets in our study, this might suggest that including Malaysia, Thailand and Korea in an investor's portfolio would be advantageous should an investor want to diversify their portfolio. However, other considerations such as the political and economic situation of these countries also have to be taken into account because their stock markets are vulnerable to shocks from all aspects, which will then also be reflected in the performance of their stock markets.

Lack of cointegration in the entire period may be due to the period being too long and there being many changes in the market conditions for different countries. Hence, we now present the trend of co-movements between the developed and emerging markets over the three sub-periods within which the market situation is likely to be more similar, and thus enhancing the possibility of cointegration. For the period 1981-1986 as indicated in Table 1, no co-movements were found for the countries in our study. This could be explained by the emerging markets being relatively closed to the outside world during this sub-period, compared to the later sub-periods because most of the emerging markets (excluding Singapore and Hong Kong) had not yet liberalized their stock markets. With such restricted markets, the amount of trade flows between these emerging markets and the developed markets was relatively low. Even in the case of Singapore and Hong Kong, the amount of trade flows between them and the developed markets was also relatively low compared to the later sub-periods. Thus the level of economic integration is not strong in this sub-period and hence it 
is not surprising that no significant relationship is observed between the developed and emerging markets.

1987-1996 encompasses the period when the United States stock market declined from its peak, crashed in October 1987 (Black Monday), and the years immediately following the crash. During this period, co-movement exists between most of the emerging and developed markets. The observed co-movements in Table 1 could be due to the emerging markets opening up their economies during this period. With less capital controls, more investments from the developed countries begin to flow into these emerging economies. The amount of trade flows between the developed and emerging markets also show an overall increasing trend which indicates the improving economic relationships between the developed and emerging markets. As research ${ }^{8}$ has shown that economic and financial relationships are linked, this overall trend of increasing importance of trade links does at least partly account for the observed increase in significant co-movements between developed and emerging markets in this sub-period.

Similar reasoning of the overall increase in trade flows also applies to the third sub-period 1997-2002, which commences with the 1997 Asian Financial Crisis. Although trade flows declined in the initial years of this sub-period due to the Crisis, the emerging markets had already been officially liberalized, resulting in a further overall increase in trade flows in this sub-period compared to Period 2 (see Table 1). This rise in economic activity between the developed and emerging markets resulting in an impact on the financial markets, with an increase in significant relationships between most of the developed and emerging markets.

From the above, we emphasize the closer relationship between emerging and developed markets after the 1987 Stock Market Crash (Period II) compared to sub-period 1. This relationship is further intensified in Period 3 after the 1997 Asian Financial Crisis. This intensifying interdependence between the developed and emerging markets in our study reflects the increased level of economic and financial integration since the liberalization of the developed markets. This situation also decreases the range of stocks available to diversify a portfolio through international diversification in order to minimize risk and maximize returns.

\section{Conclusion}

This study investigates the relationship between the major developed markets of United States, United Kingdom and Japan with the emerging markets of Malaysia, Thailand, Korea, Taiwan, Singapore and Hong Kong. We find that Singapore and Taiwan are cointegrating with Japan while 
Hong Kong is cointegrating with the United States and the United Kingdom. There are no long run equilibrium relationship between Malaysia, Thailand and Korea and the developed markets of the United States, the United Kingdom and Japan. The relationship between the developed and emerging markets also change over time, as shown by the differing comovements between them in each of the sub-periods. Furthermore, an increasing interdependence between most of the developed and emerging markets is observed after the 1987 Stock Market Crash. This interdependence also is intensified after the 1997 Asian Financial Crisis. As a result of more markets moving together, the aim of international portfolio diversification to minimize risk is more limited after the 1987 Stock Market Crash. This limitation is further exemplified after the 1997 Asian Financial Crisis. Finally we conclude that findings on the differential co-movements between the developed and emerging markets can lead to further insights into socioeconomic connections and provide useful information to both domestic and foreign investors.

\section{Acknowledgments}

We thank Mahyar A. Amouzegar, Chin Diew Lai and the anonymous referees for their valuable comments that have significantly improved this manuscript. The first author would like to thank Robert B. Miller and Howard E. Thompson for their continuous guidance and encouragement. The research is partially supported by the grant numbered R-122-000-082112 from National University of Singapore.

\section{Notes}

1. See Bekaert and Harvey (2000), and Phylaktis and Ravazzolo (2002).

2. This date is chosen because much liberalization clustered in the 1980s.

3. The stock index data for Taiwan is only available from 1 August 1994 to 31 December 2002 and the data for Singapore is only available from 1 January 1985 to 31 December 2002.

4. Black Monday, as the Stock Market Crash on October 17, 1987 is called, saw the biggest ever one-day plunge in stock prices. The Standard and Poor's Index of 500 stocks (S\&P 500) fell $20 \%$, coming on top of an overall decline of $16 \%$ since the market's peak in August 1987. With this unexpected event coming from the world's leading market, this stock market crash had a major impact on global financial markets. 
5. The start of the Asian Financial Crisis can be indicated by the Central Bank of Thailand changing the Thai exchange rate from the multicurrency basket system to the managed floating system on July 2, 1997. This event triggered off the devaluations in other Asian countries and finally caused the Asian foreign exchange and financial crises.

6. For all series, we further test for $I(2)$ and our findings reject the series to be $I(2)$ and hence we conclude that the series are $I(1)$. We do not present the $I(2)$ results, which are available on request.

7. The results are available on request.

8. Phylaktis and Ravazzolo (2002).

\section{References}

1. Arshanapalli, B. and J. Doukas. International Stock Market Linkage: Evidence from the pre- and post-October 1987 Period, Journal of Banking and Finance, 17, 193-208, 1993.

2. Bekaert, G. and C.R. Harvey. Capital Flows and The Behavior of Emerging Market Equity Returns, NBER Working Paper w6699, 1-77, 1998.

3. Bekaert, G. and C.R. Harvey. Foreign Speculation and Emerging Equity Markets, Journal of Finance, 55, 565-613, 2000.

4. Bodie, Z., Kane, A. and A.J. Marcus. Investments, 4th Edition, McGraw Hill, 1999.

5. Box, George E.P., Gwilym M. Jenkins and Gregory C. Reinsel. Time Series Analysis Forecasting and Control, 3rd. Edition, Prentice-Hall, Inc., 1994.

6. Chan, K.C., B.E. Cup and M.S. Pan. An Empirical Analysis Of Stock Prices in Major Asian Markets and the United States, The Financial Review, 27(2), 289-308, 1992.

7. Chan, K.C., B.E. Cup and M.S. Pan. International stock market efficiency and integration: A study of eighteen nations, Journal of Business Finance $\mathcal{E}$ Accounting, 24(6), 803-814, 1997.

8. Cheung, Y.L. and S.C. Mak. A Study of the International Transmission of Stock Market Fluctuation Between the Developed Markets and the Asian-Pacific Markets, Applied Financial Economics, 2, 1-5, 1992.

9. Corhay, A., A. Rad and J. Urbain. Long-run behavior of Pacific-Basin stock prices, Applied Financial Economics, 5, 11-18, 1995

10. Dickey, D. and W. Fuller. Likelihood ratio statistics for autoregressive time series with unit roots, Econometrica, 49(4), 1057-72, 1981.

11. Dolado, J., T. Jenkinson, and S. Sosvilla-Rivero. Cointegration and unit roots, Journal of Economic Surveys, 3, 251-76, 1990.

12. Engle, Robert F., and C.W.J. Granger. Cointegration and error correction: representation, estimation and testing, Econometrica, 55, 251-76, 1987.

13. Eun, Cheol S. and Sangdal Shim. International Transmission of Stock Market Movements, Journal of Financial and Quantitative Analysis, 24, 241-56, 1989.

14. Ghosh, A., R. Saidi, and K.H. Johnson. Who moves the Asia-Pacific stock markets US or Japan? Empirical evidence based on the theory cointegration, The Financial Review, 34, 159-170, 1999.

15. Granger, C. Some properties of time series data and their use in economic model specification, Journal of Econometrics, 29, 121-30, 1981.

16. Granger, C.W.J. Developments in the study of cointegrated economic variables, Bulletin of Economics and Statistics, 48, 213-28, 1987. 
17. Grubel, Herbert G. and Kenneth Fadner. The Interdependence of International Equity Markets, Journal of Finance, 26, 89-94, 1971.

18. Hamilton, J. Time Series Analysis, 1st Edition, Princeton University Press, 1994.

19. Harrison, M. The Euromoney Annual Report and the Exchange Arrangements and Restrictions, IMF, in IFC's Factbook, 1994.

20. Harvey C. R. The World Price of Covariance Risk, Journal of Finance, 46, 111-57, 1991.

21. Hilliard Jimmy E. The Relationship Between Equity Indices on the World Exchange, Journal of Finance, 34, 103-14, 1979.

22. Hung, B. and Y.L. Cheung Interdependence of Asian emerging equity markets, Journal of Business Finance \& Accounting, 22, 281-8, 1995.

23. Kasa, K.Common Stochastic trends in international stock markets, Journal of Monetary Economics, 29, 95-124, 1992.

24. Koop, Gary An Objective Bayesian Analysis of Common Stochastic Trends in International Stock Prices and Exchange Rates, Journal of Empirical Finance, 1, 343-64, 1994.

25. Krenin, M.E., M.G. Plummer, and S. Abe. Export and Direct Investment Links. M. E. Krenin, M.G. Plummer (eds.), Economic Integration in Asia, Edward Elgar, 2000.

26. Kwan, A.C.C., A.B. Sim and J.A. Cotsomitis, The casual relationship between equity indices on world exchanges, Applied Economics, 27, 33-37, 1995.

27. Levy, Haim, and Marshall Sarnat. International Diversification of Investment Portfolios, American Economic Review, 60, 668-75, 1970.

28. Maldonado, Rita, and Anthony Saunders. International Portfolio Diversification and the Inter-Temporal of International Stock Market Relationships 1957-1978, Financial Management, 10, 54-63, 1981.

29. Manzur, M., W.K. Wong and I.C. Chau. Measuring international competitiveness: experience from East Asia, Applied Economics, 31, 1383-91, 1999.

30. Panton, Donald B., V. Parker Lessig and O. Maurice Joy. Comovements of International Equity Markets: A Taxonomic approach, Journal of Financial and Quantitative Analysis, 11, 415-32, 1976.

31. Penm, J. H.W., R.D. Terrell and W.K. Wong. Causality and Cointegration Tests in the Framework of A Single Zero-Non-Zero Vector Time Series Modelling, Pakistan Journal of Applied Sciences, 3(4), 247-255, 2003.

32. Perman, R. Cointegration: An Introduction to the literature, Journal of Economic Studies, 18, 3-30, 1991.

33. Phylaktis, Kate and Fabiola Ravazzolo. Measuring Financial and Economic Integration with Equity Prices in Emerging Markets, Journal of International Money and Finance, 21, 879-903, 2002.

34. Ripley, Duncan. Systematic Elements in the Linkage of National Stock Market Indices, The Review of Economics and Statistics, 15, 356-61, 1973.

35. Taylor, Mark P. and Ian Tonks. The Internationalization of Stock Markets and The Abolition of U.K Exchange Control, Review of Economics Statistics, 71, 332-36, 1989.

36. Tiku, M.L. and W.K. Wong. Testing for unit root in AR(1) model using three and four moment approximations, Communications in Statistics: Simulation and Computation, 27(1), 185-98, 1998.

37. Tiku, M.L, W.K. Wong, D.C. Vaughan and G. Bian. Time series models with nonnormal innovations: symmetric location-scale distributions, Journal of Time Series Analysis, 21(5), 571-96, 2000.

38. Tuluca, Sorin A., and Burton Zwick. The effects of the Asian Crisis on Global Equity Markets, the Financial Review, 36, 125-142, 2001. 
39. Watson. J. The Stationary of Inter-Country Correlation Coefficients: A Note, Journal of Business Finance and Accounting, 7, 297-303, 1980. 


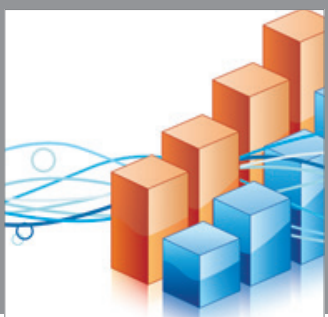

Advances in

Operations Research

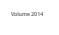

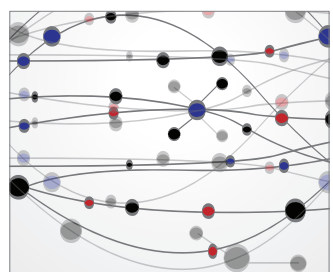

\section{The Scientific} World Journal
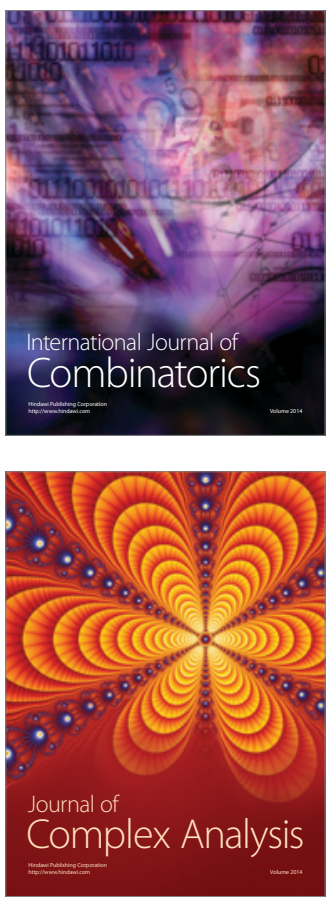

International Journal of

Mathematics and

Mathematical

Sciences
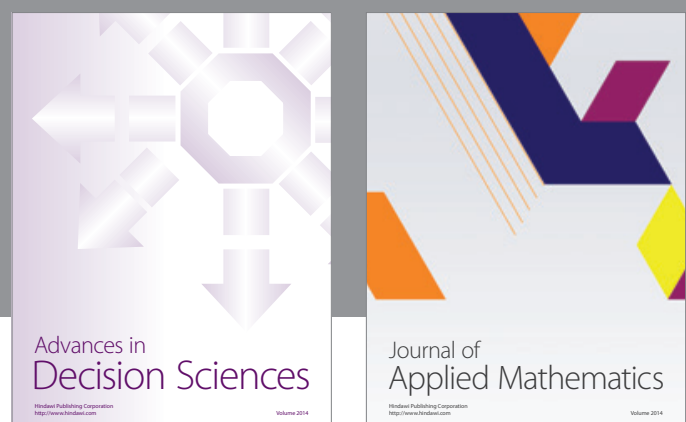

Journal of

Applied Mathematics
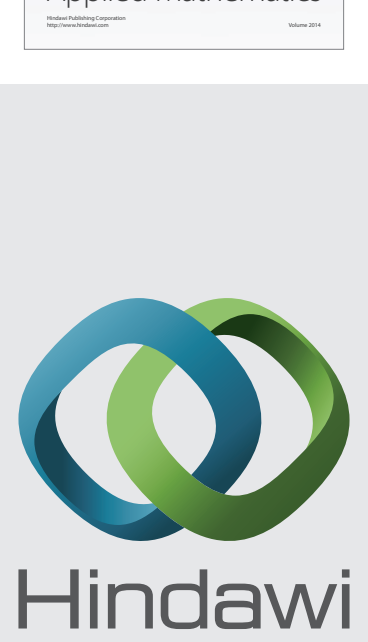

Submit your manuscripts at http://www.hindawi.com
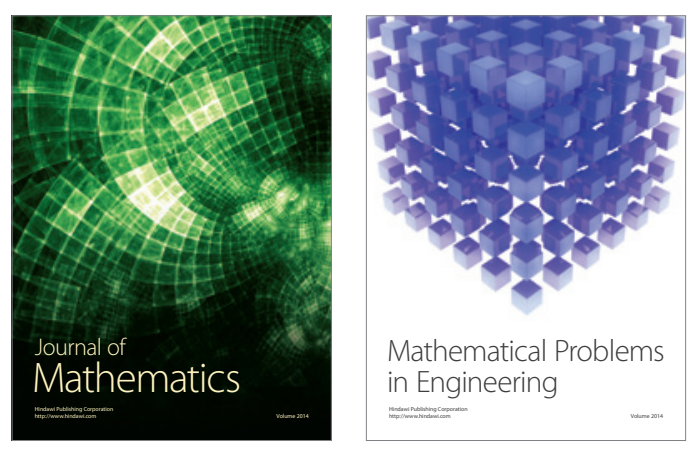

Mathematical Problems in Engineering
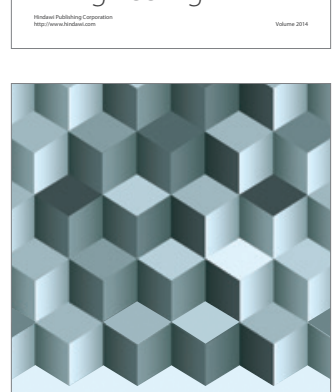

Journal of

Function Spaces
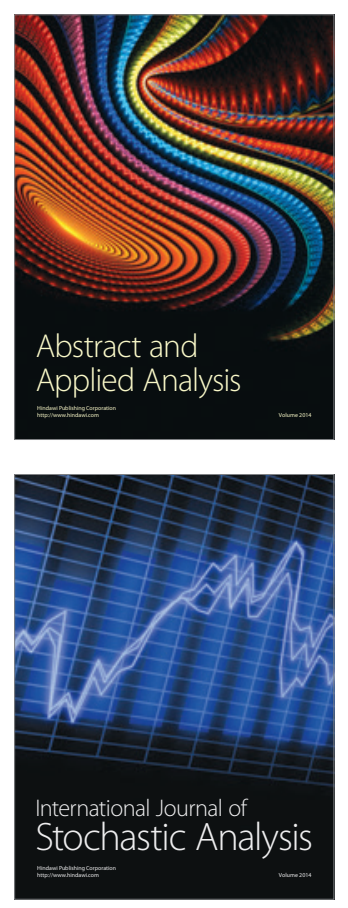

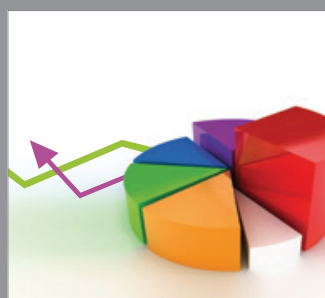

ournal of

Probability and Statistics

Promensencen
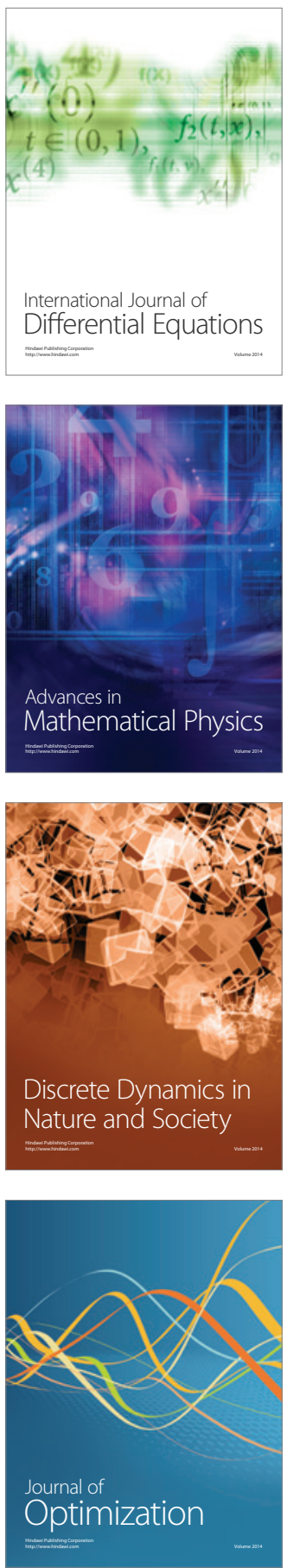